JAMP: Jurnal Adminitrasi dan Manajemen Pendidikan

Volume 2 Nomor 4 Desember 2019, Hal : 232-237

Tersedia Online di http://journal2.um.ac.id/index.php/jamp/

ISSN 2615-8574 (online)

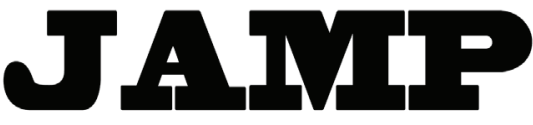

JURNAL ADMINISTRASI DAN MANAJEMEN PENDIDIKAN

\title{
SISTEM PENGASUHAN DALAM KURIKULUM KHUSUS SEBAGAI PEMBENTUKAN KARAKTER DI SMA BERBASIS KETARUNAAN
}

\author{
Nisa Rahma Danti \\ Djum Djum Noor Benty \\ Ahmad Nurabadi
}

\author{
Universitas Negeri Malang, Jl. Semarang No. 5 Malang 65145 \\ Email: nissarahma64@gmail.com
}

\begin{abstract}
The purpose of this research was to provide information about parenting systems in high school based on comprehension. This research uses a qualitative approach with case studies. Data collection techniques in the form of interviews, observation, and documentation. The process of data analysis using the data analysis process model Miles and Huberman. The results of this study: (1) the care system has three programs developed, namely, study night, self-habituation in the dormitory, physical fitness; (2) character formation stage through parenting consists of three stages, namely, the stage of formation, development and stabilization that is adjusted based on the level; (3) the main characters formed in the care system include, the character of discipline, love for the homeland and nation, tanggon, tough, trengginas, independent, superior, religious; (4) obstacles are found regarding the imbalance of numbers between caregivers and students, and permits that are still not effective; (5) completed by cooperating with each other and coordinating between caregivers and boarding management.
\end{abstract}

Keywords: parenting system, character building, cadets school

\begin{abstract}
Abstrak: Tujuan penelitian ini adalah untuk memberikan informasi mengenai sistem pengasuhan di SMA berbasis ketarunaan. Penelitian ini menggunakan pendekatan kualitatif dengan studi kasus. Teknik pengumpulan data berupa wawancara, observasi, dan dokumentasi. Proses analisis data dengan menggunakan proses analisis data model Miles dan Huberman. Hasil penelitian ini: (1) sistem pengasuhan mempunyai tiga program yang dikembangkan yaitu, study night, pembiasaan diri di asrama, kesamaptaan jasmani; (2) tahap pembentukan karakter melalui pengasuhan tertiri dari tiga tahap yaitu, tahap pembentukan, pengembangan dan pemantapan yang disesuaikan berdasarkan jenjangnya; (3) karakter utama yang dibentuk dalam sistem pengasuhan antara lain yaitu, karakter kedisiplinan, cinta tanah air dan bangsa, tanggon, tangguh, trengginas, mandiri, unggul, religius; (4) ditemukan hambatan mengenai belum seimbangnya jumlah antara pengasuh dengan peserta didik, serta perizinan yang masih belum efektif; (5) diselesaikan dengan saling bekerjasama dan berkoordinasi antara pengasuh dengan pihak manajemen asrama.
\end{abstract}

Kata kunci: sistem pengasuhan, pembentukan karakter, sekolah berbasis ketarunaan

Tujuan pendidikan tidak lain adalah untuk menambah pengetahuan dan wawasan untuk digunakan sebagai bekal dalam hidup bermasyarakat. Sependapat dengan hal tersebut menurut Undang-Undang Nomor 20 Tahun 2003 Tentang Sistem Pendidikan Nasional Pasal 3 halaman 7 menyebutkan bahwa tujuan pendidikan nasional berfungsi mengembangkan kemampuan dan membentuk watak serta peradaban bangsa yang bermartabat dalam rangka mencerdaskan kehidupan bangsa, bertujuan untuk berkembangnya potensi peserta didik agar menjadi manusia yang beriman dan bertaqwa kepada Tuhan Yang Maha Esa, berakhlak mulia, sehat, berilmu, cakap, kreatif, mandiri, dan menjadi warga negara yang demokratis serta bertanggung jawab. Berdasarkan tujuan pendidikan nasional SMAN Taruna Nala 
Jawa Timur mempunyai visi "Terwujudnya lulusan yang unggul, mandiri, kompetitif, dan berkarakter serta cinta tanah air dan bangsa". SMAN Taruna Nala Jawa Timur merupakan sekolah negeri unggulan dengan mengembangkan sekolah berasrama dan merupakan satu-satunya sekolah SMA negeri yan berbasis ketarunaan.

Upaya sekolah untuk mencapai tujuan pendidikan, SMAN Taruna Nala Jawa Timur dibagi dalam tiga aspek kegiatan, yaitu pembelajaran, pelatihan dan pengasuhan. Ketiga aspek kegiatan tersebut merupakan satu kesatuan yang bulat dan utuh saling mengisi dan saling tergantung satu dengan yang lain guna menghasilkan peserta didik yang profesional. Ketiga aspek tersebut terangkum dalam kurikulum umum 2013 serta kurikulum khusus bela negara dan kemaritiman. Alasan sekolah menambahkan kurikulum khusus bela negara dan kemaritiman adalah tidak lain untuk membentuk karakter peserta didik. Kurikulum bela negara mengolah keseluruhan aspek perilaku siswa, baik dari aspek kognitif, afektif dan psikomotor. Aspek kognitif diolah dengan proses pembelajaran klasikal, aspek afektif diolah dengan pengasuhan dan aspek psikomotor diolah dengan latihan.

Pembentukan karakter di SMAN Taruna Nala salah satunya adalah melalui pengasuhan. Hakikatnya pengasuhan adalah usaha memberikan bimbingan dan penyuluhan dalam rangka menanamkan serta memantapkan nilai-nilai budaya bangsa dan penguasaan akademik untuk membentuk insan yang berkepribadian lulur dengan menitik beratkan pada aspek kejuangan. Sedangkan menurut Hoghughi (dalam Nefrijayanti, 2018) pengasuhan merupakan hubungan antara orang tua dan anak yang multidimensi dapat berkembang, mencakup beragam aktivitas dengan tujuan anak mampu berkembang secara optimal dan dapat bertahan hidup dengan baik biasanya dibagi menjadi tiga komponen yaitu pengasuhan fisik, pengasuhan emosi dan pengasuhan sosial.

Tujuan dari sistem pengasuhan adalah untuk membentuk, menumbuh kembangkan dan memantapkan kepribadian sehingga tercapai kedewasaan watak, kemandirian iklim akademik dan menumbuhkan jiwa juang siswa sehingga tumbuh menjadi pribadi yang tanggap, tanggon, dan trengginas. Sistem pengasuhan Siswa adalah "Tri Tunggal Pusat", suatu sistem pengasuhan yang mengacu kepada tiga sumber pengaruh sentral (Sekolah, Keluarga dan Masyarakat) yang berlangsung secara simultan dan saling mempengaruhi dalam proses pertumbuhan kepribadian individu. Metode Pengasuhan.Pengasuhan Siswa dilaksanakan dengan metode "Among", suatu metode pengasuhan yang berprinsip silih asah, silih asih dan silih asuh.

Berdasarkan uraian tersebut, penelitian ini bertujuan untuk mengkaji mengenai sistem pengasuhan di SMAN Taruna Nala Jawa Timur, program apa saja yang dikembangkan dalam sistem pengasuhan, bagaimana tahapan pada sistem pengasuhan, hambatan yang dihadapi pada sistem pengasuhan, solusi atau alternatif untuk mengatasi hambatan pada sistem pengasuhan.

Tujuan penelitian ini untuk mendeskripsikan mengenai (1) sistem pengasuhan dalam kuikulum khusus di SMAN Taruna Nala Jawa Timur, (2) karakter yang dikembangkan dalam sistem pengasuhan dalam kurikulum khusus di SMAN Taruna Nala Jawa Timur, (3) hambatan yang dihadapi pada sistem pengasuhan dalam kurikulum khusus di SMAN Taruna Nala Jawa Timur, (4) solusi atau alternatif yang dilakukan untuk mengatasi hambatan dalam sistem pengasuhan dalam kurikulum khusus di SMAN Taruna Nala Jawa Timur.

\section{METODE}

Pendekatan yang digunakan dalam penelitian ini adalah pendekatan kualitatif dengan jenis penelitian studi kasus. Melalui studi kasus penelitian ini bertujuan untuk mendeskripsikan dan mengkaji lebih dalam mengenai sistem pengasuhan dalam kurikulum khusus di SMAN Taruna Nala Jawa Timur. Penelitian tentang sistem pengasuhan dalam kurikulum khusus sebagai pembentukan karakter di SMA berbasis ketarunaan di SMAN Taruna Nala Jawa Timur dilakukan karena sekolah menengah tersebut menerapkan kurikulum khusus sebagai penunjang kurikulum nasional yang memuat sistem pengasuhan sebagai salah satu alternatif pembentukan karakter peserta didik. Penelitian ini dilakukan pada latar yang alamiah dan melihat respon yang saling terkait, utuh dan menyeluruh. Rancangan penelitian ini dibuat bersifat sementara dan sewaktu-waktu dapat berubah dan berkembang sesuai dengan kondisi di lapangan. Peneliti merupakan instrumen kunci dalam penelitian. Guna mendapatkan data yang 
akurat peneliti menggunakan beberapa teknik pengumpulan data dalam penelitiannya yaitu wawancara, observasi, dan dokumentasi.

\section{HASIL}

\section{Sistem Pengasuhan dalam Kurikulum Khusus di SMAN Taruna Nala Jawa Timur}

Sistem pengasuhan pada kurikulum BNK dilaksankan berdasarkan sistem Tritunggal Pusat yang mengacu pada tiga sumber yaitu sekolah, keluarga, serta masyarakat yang berlangsung secara stimulan dan saling mempengaruhi satu sama lain dalam proses pembentukan kepribadian peserta didik. Berdasarkan sistem tersebut terdapat asas yang mendasarinya antara lain yaitu (1) asas manfaat, (2) asas keutuhan, (3) asas keselarasan, (4) asas percaya kepada kemampuan diri sendiri, (5) asas keterbukaan, (6) asas orientasi masa depan. Sedangkan metodenyang digunakan dalam sistem pengasuhan ada tiga metode yaitu silih asah, silih asih, dan silih asuh. Pendekatan yang digunakan ada tiga yaitu ing ngarso sung tulodo, ing madyo mangun karso, tut wuri handayani.

Program yang dikembangkan dalam sistem pengasuhan untuk membentuk karakter peserta didik anatara lain yaitu, (1) study night, merupakan program akademik yang berbentuk bimbingan belajar di malam hari dengan didampngi oleh guru mata pelajaran; (2) program kesemaptaan jasmi, merupakan suatu program yang dikembangkan dengan tujuan agar peserta didik mempunya fisik yang sehat dan kuat, yang terdiri dari senam, lari, sit up, pull up, bela diri militer, renang dan selam; (3) program pembiasaan diri, merupakan suatu program dimana kegiatan ini dilaksanakan diawal tahun ajaran baru yang dikhususkan bagi peserta didik kelas X program ini biasa disebut dengan masa basis dimana peserta didik tidak boleh berinteraksi dengan lingkungan luar asrama. Sedangkan tahap pengasuhan dibagi menjadi tiga tahapan yaitu (1) tahap pembentukan untuk kelas X; (2) tahap pengembangan untuk kelas XI, serta (3) tahap pemantapan untuk kelas XII. Saat melaksanakan pengasuhan sekolah menggungakan 8 teknik dasar antara lain yaitu (1) intruksi, (2) persuasi, (3) stimulasi, (4) santi aji, (5) santi karma, (6) pembinaan tradisi, (7) pemberian penghargaan, (8) pemberian hukuman.

\section{Karakter yang Dibentuk pada Sistem Pengasuhan dalam Kurikulum Khusus di SMAN Taruna Nala Jawa Timur}

Pendidikan karakter dilaksanakan melalui beberapa aspek yang pertama yaitu pembelajaran klasikal dimana peserta didik memperoleh materi yang termuat dalam dua mata pelajaran kurikulum khusus ini, yaitu mata pelajaran bela negara dan mata pelajaran kemaritiman. Kedua adalah aspek keterampilan dimana peserta didik mendapatkan pelatihan keterampilan khas ketarunaan dan kemaritiman yang dilatih langsung oleh tim khusus dari TNI AL melalui Lapetal yaitu kesamaptaan jasmani yang terdiri dari push up, sit up, pull up, senam, lari, bela diri militer, kemuadian untuk yang kemaritiman peserta didik dilatih berenang dan menyelam. Ketiga adalah melalui pengasuhan sendiri dimana peserta didik dibina dan dibimbing melalui pembiasaan-pembiasaan yang telah diatur dalam PERDUPDIK mulai bangun pagi sampai dengan istirahat malam. Beberapa kegiatan kepengasuhan yang dilaksanakan selama keseharian oleh siswa diantaranya adalah jaga serambi, apel pagi \& malam, jaga penanting, jaga siswa, apel lorong, ronda malam, sholat berjamaah, penaikan dan penurunan bendera, serta makan bersama. Pada saat puasa jadwal keseharian peserta didik hampir sama, hanya berbeda pada waktu sarapan pagi yang digantikan dengan sahur bersama. Keempat, peneliti menemukan dalam buku pedoman jika pelaksanaan pembentukan karakter didasarkan pada teori kultivasi karakter yang berisikan tentang proses pembentukan karakter mulai dari menetapkan tujuan, seleksi peserta didik, pengelolaan kondisi lingkungan yang baik, penanaman nilai-nilai karakter, selalu menjaga nilai-nilai karakter, serta peningkatan kondisi lingkungan yang kondusif dan kontributif.

\section{Hambatan dan Solusi pada Sistem Pengasuhan dalam Kurikulum Khusus di SMAN Taruna Nala Jawa Timur}

Penerapan Pengasuhan tentu saja tidak berjalan mulus, hambatan dalam penerapannya yaitu, (1) SMAN Taruna Nala Jawa Timur memiliki jumlah pengasuh yang kurang, sebab kebutuhan jumlah 
pengasuh yang kurang efektif; (2) Perizinan peserta didik yang sering mengalami kontra kewenangan perizinan yang diberikan oleh pihak Asrama dengan pihak Pengasuh.

Solusi yang ditawarkan sekolah dalam menghadapi hambatan yang muncul yaitu antara lain, (1) mengajukan penambahan tenaga pengasuh, (2) saling bekerja sama dalam menjalankan tugas sebagai pengasuh, (3) membentuk piket jaga dan bekerjasama dengan pihak asrama, (4) pihak manajemen asrama berencana untuk mengusulkan kepada kepala sekolah bahwa sebaiknya perizinan siswa sepenuhnya diserahkan kepada pengasuh, (5) saling koordinasi antara pihak asrama dengan pengasuh.

\section{PEMBAHASAN}

\section{Sistem Pengasuhan dalam Kurikulum Khusus di SMAN Taruna Nala Jawa Timur}

Sekolah menerapkan Kurikulum 2013 sebagai dasar pembelajaran di sekolah dan dipadukan dengan Kurikulum Khusus sebagai salah satu upaya sekolah membentuk karakter peserta didik yang cinta tanah air dan bangsanya. Hal ini sejalan dengan Undang-Undang Dasar 1945 dimana pada Pasal 27 ayat (3) disebutkan bahwa "setiap warga negara berhak dan wajib ikut serta dalam upaya pembelaan negara". Sistem pendidikan di SMAN Taruna Nala Jawa Timur dibagi menjadi tiga yaitu pembelajaran, latihan, dan pengasuhan. (1) pembelajaran, ditekankan pada aspek intelektual dan akademik dengan menggunakan sistem ceramah dan pembelajaran berada di dalam kelas; (2) latihan, ditekankan pada aspek kesamaptaan jasmani yaitu, olahraga, renang, selam dan yang berhubungan dengan olah fisik peserta didik; serta (3) pengasuhan, yaitu berwujud bimbingan terhadap peserta didik dengan menekankan nilainilai karakter dan pelaksanaannya lebih banyak di Asrama sekolah. Senada dengan hal tersebut bahwa didalam Undang-Undang Sisdiknas Tahun 2003 Pasal 37 menyebutkan bahwa kurikulum pendidikan dasar dan menengah wajib memuat, pendidikan agama, pendidikan kewarganegaraan, bahasa, matematika, ilmu pengetahuan alam, ilmu pengetahuan sosial, seni dan budaya, pendidikan jasmani dan olahraga, keterampilan, muatan lokal. Dalam mewujudkan isi kurikulum tersebut sekolah membuat sistem pendidikan yang telah dijelaskan diatas.

Arti pengasuhan menurut buku pedoman pengasuhan SMAN Taruna Nala Jawa Timur adalah pembentukan karakter dan transformasi nilai-nilai bela negara/kejuangan. Berbentuk bimbingan dan pengasuhan dengan sasaran menanamkan kemandirian dan memantapkan nilai-nilai bela negara/ kejuangan, menitik beratkan aspek mental kepribadian agar terbentuk karakter dan kepribadian yang tanggon. Sedangkan menurut Hoghughi (dalam Nefrijayanti, 2018) pengasuhan diartikan sebagai hubungan antara dua orang dan anak yang multidimensi dapat berkembang, mencakup beragam aktivitas dengan tujuan anak mampu berkembang secara optimal dan mampu bertahan hidup dengan baik, dan biasanya dibagi menjadi tiga komponen yaitu pengasuhan fisik, pengasuhan emosi dan pengasuhan sosial.

Metode pengasuhan di SMAN Taruna Nala Jawa Timur dilaksanakan dengan metode among yaitu suatu metode pengasuhan yang berprinsip silih asah silih asih dan silih asuh. Silih asah. Paparan tersebut sama halnya dengan penjelasan dari Lestari, S (2012) yaitu dalam mengasuh terkandung makna menjaga/ merawat /mendidik, membimbing/ membantu/ melatih, memimpin/ mengepalai/ menyelenggarakan. Istilah asuh sering dirangkaikan dengan asah dan asih menjadi asah-asih-asuh. Mengasah berarti melatih agar memiliki kemampuan atau kemampuannya meningkat. Mengasihi berarti mencintai dan menyayangi. Dengan rangkaian kata asah-asih-asuh, meka pengasuhan anak bertujuan untuk meingkatkan atau mengembangkan kemampuan anak dan dilakukan dengan dilandasi rasa kasih sayang tanpa pamrih. Tahap-tahap pengasuhan di SMAN Taruna Nala Jawa Timur menggunakan tiga tahap pengasuhan dengan sistem tingkatan, antara lain yaitu tahap pembentukan untuk kelas $\mathrm{X}$, tahap pengembangan untuk kelas XI, serta tahap pemantapan untuk kelas XII.

\section{Karakter yang Dibentuk pada Sistem Pengasuhan dalam Kurikulum Khusus di SMAN Taruna Nala Jawa Timur}

SMAN Taruna Nala Jawa Timur mempunyai cara lain tersendiri dalam membentuk karakter peserta didiknya. SMAN Taruna Nala Jawa Timur selain berpedoman pada kurikulum 2013 juga menambahkan 
kurikulum khusus bela negara dan kemaritiman sebagai salah satu cara untuk membentuk karakter peserta didik. Hal tersebut sama dengan pendapat dari Kurniawan, S (2013) bahwa agar bisa efektif pendidikan karakter sebaiknya perlu dikembangkan sendiri oleh sekolah dalam implementasinya, misalnya menambahkan program tersendiri atau juga bisa melalui transformasi budaya di sekolah.

SMAN Taruna Nala Jawa Timur dalam melaksanakan penguatan pendidikan karakter (PPK) melalui kurikulum khususnya mempunya model pengembangan kurikulum yaitu, (1) melalui mata pelajaran bela negara dan kemaritiman yang dilaksanakan dengan cara pembelajaran klasikal; (2) melalui latihan yaitu peserta didik dilatih kekuatan fisiknya melalui bela diri militer, renang, dan selam; (3) melalui pengasuhan dimana pengasuh membimbing dan mendampingi peseserta didik mulai dari bangun pagi sampai dengan waktu tidur; (4) kultivasi karakter, yaitu merupakan suatu cara pengolahan karakter pada peserta didik baik di sekolah maupun luar sekolah. Hal tersebut sama dengan pendapat Mulyasa (2013) menegenai model model pengembangan kurikulum pendidikan karakter di sekolah yang dapat dilaksanakan dalam 5 (lima) model yaitu, (1) model subjek matter yitu pengemabangan pendidikan karakter melalui mata pelajaran tersendiri; (2) model kolerasi dalam mata pelajaran sejenis; (3) model intergrasi dalam seluruh mata pelajaran; (4) model suplemen, yaitu pelaksanaan pendidikan karakter melalui sebuah kegiatan luar jam sekolah; (5) model gabungan, yaitu gabungan dari beberapa model diatas.

\section{Hambatan yang Dihadapi pada Sistem Pengasuhan dalam Kurikulum Khusus di SMAN Taruna Nala Jawa Timur}

Kurangnya tenaga Pengasuh menjadi salah satu masalah sebab kebutuhan pengasuh yang efektif seharusnya memiliki perbandingan 1:30 akan tetapi SMAN Taruna Nala Jawa Timur memiliki perbandingan 1:150. Perbandingan tersebut diambil dari jumlah peseta didik dibagi dengan jumlah pengasuhnya yaitu sekolah memiliki kurang 497 peserta didik dengan 3 pengasuh. Berdasarkan pernyataan dari Ibu Avi selaku Staf Kurikulum Pengasuhan bahwa "harusnya untuk pengasuh ini minimal rasio perbandingannya adalah 1:30. Dasarnya adalah dalam satu pleton itu 30 orang, karena itu lah kemampuan seseorang untuk menjangkau, mengawasi orang itu satu orang maksimal itu 30 jadi seharusnya 1:30". Menurut Permendikbud No.17 Tahun 2017 tertulis bahwa "SMA dalam satu kelas/ rombel paling sedikit adalah 20 (dua puluh) peserta didik dan paling banyak adalah 32 peserta didik". Jadi dapat disimpulkan bahwa kebutuhan pengasuh di SMAN Taruna Nala masih terbilang kurang efektif dalam melaksanakan pengasuhan karena jumlah rasio antara peserta didik dan pengasuh masih kurang.

Masalah yang kedua yaitu mengenai masalah perizinan yang masih rancu antara kewenangan Pengasuh dengan pihak asrama. Akibatnya berdampak kepada peserta didik, ketika peserta didik mengajukan perizinan. Hal ini terjadi akibat miskomunikasi antara pihak Pengasuh dengan pihak asrama, ketika pihak asrama mengizinkan peserta didik akan tetapi ternyata pengasuh tidak memberika izin kepada peserta didik.

\section{Solusi atau Alternatif Pemecahan yang Dilakukan untuk Mengatasi Hambatan pada Sistem Pengasuhan di SMAN Taruna Nala Jawa Timur}

Setiap hambatan yang muncul terdapat upaya untuk mengatasinya seperti yang dilakukan oleh SMAN Taruna Nala Jawa Timur yaitu dengan cara (1) mengajukan penambahan tenaga pengasuh; (2) saling bekerja sama dalam menjalankan tugas sebagai pengasuh; (3) membentuk piket jaga dan bekerjasama dengan pihak asrama; (4) mengusulkan kepada kepala sekolah bahwa sebaiknya perizinan siswa sepenuhnya diserahkan kepada pengasuh; (5) saling koordinasi antara pihak asrama dengan pengasuh.

\section{SIMPULAN DAN SARAN}

Kesimpulan penelitian terdiri dari 4 temuan penelitian, yang pertama sistem pengasuhan di SMAN Taruna Nala Jawa Timur mengembangkan tiga program utama yaitu study night, kesamaptaan jasmani, serta pembiasaan diri. Sistem pengasuhan terdiri dari tiga tahapan yang terbagi berdasarkan tingkatan 
atau jenjang, antara lain yaitu tahap pengembangan untuk kelas $\mathrm{X}$, tahap pembentukan untuk kelas XI, dan tahap pemantapan untuk kelas XII. Kedua, pemebentukan karakter di SMAN Taruna Nala dilaksanakan menggunakan teknik kultivasi karakter yaitu mulai dari menetapkan tujuan, seleksi peserta didik, pengelolaan kondisi lingkungan yang baik, penanaman nilai-nilai karakter, selalu menjaga nilainilai karakter, serta peningkatan kondisi lingkungan yang kondusif dan kontributif, sedangkan karakter yang dibentuk dalam sistem pengasuhan melalui program pembiasaan diri di asrama yang telah diatur dalam peraturan kehidupan peserta didik dimana semua kegiatan peserta didik mulai dari bangun pagi sampai tidur telah diatur didalamnya, karakter yang dibentuk antara lain yaitu religius, integritas, mandiri, nasionalis, gotong royong, unggul, tagguh, tanggon, dan trengginas. Ketiga, hambatan yang dihadapi pada pelaksanaan sistem pengasuhan ada dua yaitu kurang seimbangnya antara jumlah pengasuh dengan jumlah peserta didik dan masalah perizinan peserta didik yang masih mengalami kontra kewenangan antara pihak pengasuh dengan manajemen asrama. Keempat, solusi atau alternatif untuk mengatasi hambatan antara lain yaitu (1) mengajukan penambahan tenaga pengasuh; (2) saling bekerja sama dalam menjalankan tugas sebagai pengasuh; (3) membentuk piket jaga dan bekerjasama dengan pihak asrama; (4) mengusulkan kepada kepala sekolah bahwa sebaiknya perizinan siswa sepenuhnya diserahkan kepada pengasuh; (5) saling koordinasi antara pihak asrama dengan pengasuh.

Berdasarkan simpulan penelitian yang telah dijelaskan sebelumnya, maka saran peneliti kapada pihak yang terkait antara lain yaitu yang pertama bagi Kepala Cabang Dinas Pendidikan Provinsi Jawa Timur hendaknya memberikan perhatian lebih terutama dalam pelaksanaan peningkatan karakter peserta didik melalui pengasuhan serta memberikan pengawasan terhadap kegiatan pelaksanaan kurikulum bela negara dan kemaritiman di SMAN Taruna Nala Jawa Timur. Kedua, bagi Kepala SMAN Taruna Nala Jawa Timur hendaknya penerapan sistem pengasuhan di SMAN Taruna Nala Jawa Timur sudah berjalan dengan baik. Namun diharapkan kepada kepala sekolah dapat memberikan motivasi serta dukungan yang lebih agar tercapai visi, misi dan tujuan sekolah. Selain itu diharapkan kepada kepala sekolah untuk segera menyelesaikan masalah mengenai perijinan peserta didik. Ketiga, bagi Tim Pelaksana Pengasuhan SMAN Taruna Nala Jawa Timur disarankan kepada tim pelaksana pengasuhan dapat saling meningkatakan koordinasi bersama dengan pihak manajemen asrama agar tidak terjadi kesalahi pahaman mengenai perijinan peserta didik. Keempat, bagi Ketua Jurusan Admnisitrasi Pendidikan, diharapkan hasil penelitian ini dapat dijadikan salah satu referensi dalam lingkup perkuliahan yang memiliki keterkaitan dengan pendidikan karakter terutama mengenai pembentukan karakter peserta didik di sekolah berbasis ketarunaan, sehingga dapat memperluas cakupan referensi mahasiswa. Kelima, bagi Peneliti Lain, harapannya untuk peneliti lain dapat melanjutkan dan menuntaskan keterbatasan peneliti dalam menggali informasi lebih dan belum terungkap dalam pelaksanaan pembentukan karakter melalui pengasuhan pada aspek kedisiplinan. Peneliti menyarankan kepada peneliti lain untuk mendalami peran budaya ketarunaan di SMAN Taruna Nala Jawa Timur dalam membentuk karakter disiplin peserta didik.

\section{DAFTAR RUJUKAN}

Kurniawan, S. 2013. Pendidikan Karakter. Yogyakarta: AR-Ruzz Media.

Lestari, S. 2012. Psikologi Keluarga (Penananaman Nilai, Penanganan Konflik dalam Keluarga). Jakarta: Kencana Prenadamedia Group.

Mulyasa, H.E. 2013. Manajemen Pendidikan Karakter. Jakarta: Bumi Akasara.

Nefrijayanti. 2018. Definisi dan Pendapat Para Ahli Tentang Pengasuhan (parenting), (Online). (https:// pusatkemandiriananak.com/definisi-dan-pendapat-para-ahli-tentang-pengasuhan-parenting/) diakses pada 2 Januari 2019.

Peraturan Mentri Pendidikan dan Kebudayaan Nomor 17 Tahun 2017 Tentang Penerimaan Peserta Didik Baru, (Online) (https://www.kemendikbud.go.id/main/blog/2017/06/salinan-

permendikbud-nomor-17-tahun-2017-tentang-penerimaan-peserta-didik-baru), diakses pada 20 Juni 2019.

Tim Pengasuhan SMAN Taruna Nala Jawa Timur. 2017. Panduan Kurikulum Pendidikan Kemaritiman Sekolah Menengah Atas Negeri Taruna Nala Jawa Timur. Malang: SMAN Taruna Nala Jatim.

Undang-Undang Republik Indonesia Nomor 20 Tahun 2003 Tentang Sistem Pendidikan Nasional. 2016. Jakarta: Sinar Grafika. 